ARTICLE

\title{
Molecular composition of organic matter controls methylmercury formation in boreal lakes
}

Andrea G. Bravo', Sylvain Bouchet ${ }^{2}$, Julie Tolu ${ }^{3}$, Erik Björn ${ }^{2}$, Alejandro Mateos-Rivera ${ }^{1}$ \& Stefan Bertilsson ${ }^{1}$

A detailed understanding of the formation of the potent neurotoxic methylmercury is needed to explain the large observed variability in methylmercury levels in aquatic systems. While it is known that organic matter interacts strongly with mercury, the role of organic matter composition in the formation of methylmercury in aquatic systems remains poorly understood. Here we show that phytoplankton-derived organic compounds enhance mercury methylation rates in boreal lake sediments through an overall increase of bacterial activity. Accordingly, in situ mercury methylation defines methylmercury levels in lake sediments strongly influenced by planktonic blooms. In contrast, sediments dominated by terrigenous organic matter inputs have far lower methylation rates but higher concentrations of methylmercury, suggesting that methylmercury was formed in the catchment and imported into lakes. Our findings demonstrate that the origin and molecular composition of organic matter are critical parameters to understand and predict methylmercury formation and accumulation in boreal lake sediments.

\footnotetext{
${ }^{1}$ Department of Ecology and Genetics, Limnology and Science for Life Laboratory, Uppsala University, SE-75236 Uppsala, Sweden. ${ }^{2}$ Department of Chemistry, Umeå University, SE-90187 Umeå, Sweden. ${ }^{3}$ Department of Ecology and Environmental Science, Umeå University, SE-90187 Umeå, Sweden. Correspondence and requests for materials should be addressed to A.G.B. (email: andrea.garcia@ebc.uu.se).
} 
$\mathrm{H}$ umans are mostly exposed to the highly toxic methylmercury (MeHg) through fish consumption ${ }^{1}$. In the European Union alone, reducing environmental exposure to $\mathrm{MeHg}$ could save $€ 8-9$ billion per year by protecting children's brain development ${ }^{2}$. Unravelling the factors controlling the methylation of inorganic $\mathrm{Hg}(\mathrm{Hg})$ to $\mathrm{MeHg}$ in aquatic ecosystems is thus crucial for reducing such risks. $\mathrm{Hg}$ methylation is predominantly a microbial process mediated by some members of the sulphate-reducing bacteria, iron-reducing bacteria, methanogens and Firmicutes ${ }^{3,4}$. In aquatic systems, the process occurs in oxygen-deficient zones of sediments or stratified water columns ${ }^{5,6}$. A wide range of environmental factors, including temperature, $\mathrm{pH}$, redox potential and the concentration of bioavailable $\mathrm{Hg}$ are known to influence $\mathrm{Hg}$ methylation processes ${ }^{7}$. In particular, organic matter (OM) seems to play a crucial role for $\mathrm{MeHg}$ formation, acting as electron donor for $\mathrm{Hg}$ methylating bacteria ${ }^{4}$ while also binding $\mathrm{Hg}$ to regulate its bioavailability depending on the type of complexes formed ${ }^{8}$. In aquatic ecosystems, OM is an extremely heterogeneous mixture derived from a combination of terrestrial (allochthonous) or internal (autochthonous) sources with different microbial and physicochemical reactivity ${ }^{9-11}$. Because the concentration of $\mathrm{OM}$ alone cannot explain the variation in $\mathrm{Hg}$ methylation rates measured in the environment ${ }^{12}$, it has been suggested that $\mathrm{OM}$ molecular composition plays an essential role in the process ${ }^{13,14}$. For example, low ratios of elemental carbon and nitrogen contents $(\mathrm{C} / \mathrm{N})$, being a proxy for autochthonous $\mathrm{OM}$, have been associated with higher $\mathrm{Hg}$ methylation rates in estuarine and marine sediments ${ }^{13,14}$. In lakes, algae and cyanobacterial blooms have been linked to enhanced $\mathrm{Hg}$ methylation in sediments ${ }^{15}$. Moreover, it has been suggested that algal-derived compounds might be an important factor regulating the production of $\mathrm{MeHg}$ in periphyton ${ }^{16}$. Combined, these studies imply that autochthonous OM has likely a central role in $\mathrm{Hg}$ methylation processes in aquatic systems, but the coarse approaches used so far to characterize OM, such as losson-ignition $^{12}, \mathrm{C} / \mathrm{N}$ ratios $^{13,14}$ or chlorophyll $a$ measurements ${ }^{16}$, do not distinguish between specific OM compounds that may influence $\mathrm{Hg}$ methylation processes in contrasting ways. To bridge this gap in knowledge, the aim of this study was to find linkages between specific organic compounds and $\mathrm{Hg}$ methylation in boreal lake sediments by resolving and characterizing, at the molecular level, the typically complex natural OM.

Boreal biomes contain the highest density of freshwaters on Earth $^{17}$ and host about $28.4 \%$ of the global lake area (obtained by dividing the total estimated boreal lake area ${ }^{18}$ by the global lake area ${ }^{17}$ ). Boreal lakes are of special concern because they are highly sensitive to environmental changes such as terrigenous $\mathrm{OM}$ inputs and autochthonous $\mathrm{OM}$ production ${ }^{19}$. We hypothesized that, in boreal lake sediments strongly affected by different $\mathrm{OM}$ inputs, ranging from internally produced phytoplankton to terrigenous $\mathrm{OM}$ imported from the surrounding catchment, the molecular composition of the $\mathrm{OM}$ could be a major driver of $\mathrm{Hg}$ methylation. To test this, we studied a gradient of boreal lakes with contrasting OM characteristics and demonstrate that fresh phytoplanktonderived OM compounds have a strong positive influence on in situ $\mathrm{Hg}$ methylation rates. We are the first to demonstrate that $\mathrm{Hg}$ methylation rates can be predicted by sediment OM molecular composition.

\section{Results}

OM molecular composition in lake sediments. We collected sediments from 10 boreal lakes in central Sweden (Table 1) with
Table 1 | Characteristics of the investigated lakes.

\begin{tabular}{lcccccc} 
Lake & Code & $\mathbf{N}$ & $\mathbf{E}$ & $\begin{array}{c}\text { Area } \\
\mathbf{( k m}^{\mathbf{2}} \mathbf{)}\end{array}$ & $\begin{array}{c}\mathbf{z} \\
\mathbf{( m )}\end{array}$ & $\mathbf{p H}$ \\
\hline Lilla Sångaren & LS & 59.8996 & 15.3923 & 0.24 & 17 & 6.9 \\
Ljustjärn & LU & 59.92375 & 15.453472 & 0.12 & 10 & 7.3 \\
Svarttjärn & $\mathrm{S}$ & 59.89073 & 15.2577 & 0.07 & 6.5 & 5.6 \\
Fälaren & $\mathrm{F}$ & 60.33656 & 17.79396 & 2.05 & 2.0 & 7.5 \\
Oppsveten & $\mathrm{O}$ & 59.98874 & 15.57562 & 0.65 & 10 & 6.3 \\
Stransdjön & STR & 59.87099 & 17.168650 & 1.3 & 2.5 & 6.9 \\
Valloxen & V & 59.73846 & 17.83954 & 2.9 & 6 & 8.5 \\
Vallentunasjön & VALE & 59.50435 & 18.037083 & 5.8 & 4 & 7.1 \\
Marnästjärn & $\mathrm{M}$ & 60.14483 & 15.20714 & 0.15 & 2 & 7.2 \\
Lötsjön & LOTS & 59.86314 & 17.940110 & 0.63 & 7 & 6.8 \\
\hline
\end{tabular}

Location, area, maximum lake depth $(\mathrm{z})$ and $\mathrm{pH}$. Sediment cores were collected at the maximum lake depth.

different trophic status (total phosphorus, TP: $8-198 \mu \mathrm{gl}^{-1}$ ) and organic carbon concentrations (dissolved organic carbon, DOC: $3.8-33.1 \mathrm{mgl}^{-1}$; Table 2). We characterized the molecular composition of sedimentary OM by a pyrolysis-gas chromatography-mass spectrometry (Py-GC-MS) method, recently optimized for sediments ${ }^{20}$. As an analytical tool to characterize OM composition, $\mathrm{Py}-\mathrm{GC}-\mathrm{MS}$ is a good compromise between the quantitative molecular information obtained from tedious, compound specific, wet chemical extractions associated with liquid chromatography (LC)-MS or GC-MS analyses, and the qualitative, non-molecular information provided by highthroughput techniques such as visible-near-infrared spectroscopy or 'RockEval' pyrolysis. In addition to the high throughput in terms of analyses and data treatment, the Py-GC-MS method used in this study yields semi-quantitative data for more than 100 pyrolytic compounds derived from organic compounds of diverse biochemical classes (for example, lignin, chlorophyll, lipids, and so on). Hence the method makes possible to explore the overall OM molecular composition and to infer the origin and degradation status of the sediment $\mathrm{OM}^{20}$.

Differences in molecular composition of the sediment OM among the 10 lakes (Table 1) were explored using principal component analysis (PCA), performed with 110 identified pyrolytic organic compounds (Fig. 1a). The first principal component (PC1; 29\% of total variance) separated autochthonous phytoplankton-derived organic compounds (Fig. 1a, positive loadings on PC1) from plant-derived organic compounds (Fig. 1a, negative loadings on PC1). Indeed lignin oligomers, specific of vascular plants ${ }^{21}$, and phenolic compounds which derive from pyrolysis of lignin structures or originate from non-vascular plants ${ }^{22}$ had negative loadings on PC1. Positive loadings on $\mathrm{PC} 1$ were found for pyrolytic products of proteins (for example, 2.5-diketopiperazines ${ }^{23}$ ) and chlorophylls (that is, phytol, phytene, phytadiene ${ }^{24}$ ), deriving both from phytoplankton-derived materials ${ }^{25,26}$. Pyrolytic compounds characteristic for chitin structures from, for example, fungal cell walls and arthropod exoskeletons (for example, acetamidofuran and oxazoline ${ }^{27}$ ) (Fig. 1a) also presented positive loadings on PC1. The second principal component (PC2; 26\% of total variance) separated organic compounds indicative of OM degradation processes (negative loadings on PC2) from fresh plant-derived organic compounds (positive loadings on PC2). Indeed, negative loadings on PC2 were observed for pyrolytic compounds indicative of degradation products of highmolecular mass carbohydrates (for example, furans ${ }^{22}$ ); proteins and chlorophylls (for example, pyrrole, pyridine and aromatic nitriles ${ }^{28}$ ); and cell wall lipids (short-chain $n$-alkanes/alkenes with carbon number $\leq 13$ ) (Fig. 1a). The mid-chain $n$-alkenes $/ n$ - 
Table 2 | Vertical profiles of several ancillary parameters in the studied lakes.

\begin{tabular}{|c|c|c|c|c|c|c|c|c|c|c|c|c|}
\hline Sample & $\begin{array}{c}T \\
\left({ }^{\circ} \mathrm{C}\right)\end{array}$ & $\begin{array}{c}C \\
\left(\mu s^{-1}\right)\end{array}$ & $\begin{array}{c}\mathrm{O}_{2} \\
\left(\mathrm{mg} \mathrm{I}^{-1}\right)\end{array}$ & $\begin{array}{c}\text { Hgll } \\
\left(\left.n g\right|^{-1}\right)\end{array}$ & $\begin{array}{c}\text { MeHg } \\
\left(n g I^{-1}\right)\end{array}$ & $\begin{array}{c}\text { MeHg } \\
(\%)\end{array}$ & $\begin{array}{c}\text { DOC } \\
\left(\mathrm{mg} \mathrm{I}^{-1}\right)\end{array}$ & $\begin{array}{c}\text { TP } \\
\left(\mu \mathrm{g} \mathrm{I}^{-1}\right)\end{array}$ & $\begin{array}{c}\text { Chl } a \\
\left(\mu \mathrm{g} \mathrm{I}^{-1}\right)\end{array}$ & $\begin{array}{l}\text { SUVA }_{254} \\
\left(\mathrm{I} \mathrm{mg}^{-1}\right. \\
\left.\mathrm{C} \mathrm{m}^{-1}\right)\end{array}$ & $\begin{array}{c}\mathrm{SO}_{4}^{2-} \\
\left(\mathrm{mg} \mathrm{l}^{-1}\right)\end{array}$ & $\begin{array}{c}\text { BP } \\
\left(\mu \mathrm{g}^{-1} \mathrm{I}^{-1}\right. \\
\left.\mathrm{d}^{-1}\right)\end{array}$ \\
\hline LS-WC-6 & 9.4 & 42 & 8.3 & $2.3 \pm 0.1$ & $0.3 \pm 0.03$ & 10.8 & $6.3 \pm 0.2$ & 10 & 4.4 & 3.3 & 3.1 & 0.18 \\
\hline LS-WC-16 & 5.3 & 43 & 6.4 & $2.3 \pm 0.0$ & $0.2 \pm 0.03$ & 9.6 & $6.0 \pm 0.5$ & 10 & 0.0 & 3.8 & 3.2 & 0.15 \\
\hline LS-OW-17 & 5.0 & 60 & 4.7 & $4.0 \pm 0.1$ & $0.8 \pm 0.04$ & 16.0 & $7.0 \pm 1.0$ & 23 & 1.8 & 4.2 & 2.9 & 0.10 \\
\hline LJU-WC-2 & 16.9 & 18.8 & 9.2 & ND & ND & ND & $3.8 \pm 0.1$ & 8 & 2 & 1.2 & 2.1 & 1.15 \\
\hline LJU-WC-8 & 7.8 & 16.4 & 0.9 & ND & ND & ND & $3.7 \pm 0.4$ & 17 & 16 & 1.3 & 2.1 & 0.84 \\
\hline LJU-OW-10 & 6.9 & 77.2 & 0.2 & ND & ND & ND & $6.5 \pm 0.3$ & 96 & 93 & 1.6 & 2.2 & 0.24 \\
\hline S-WC-1 & 15.0 & 45 & 4.7 & $7.3 \pm 0.5$ & $0.8 \pm 0.05$ & 9.5 & $26.2 \pm 1.0$ & 11 & 0.0 & 5 & 1.6 & 0.46 \\
\hline S-WC-3 & 7.0 & 42 & 3.4 & $4.3 \pm 0.1$ & $0.5 \pm 0.03$ & 10.6 & $19.2 \pm 2.0$ & 15 & 0.0 & 5.2 & 1.9 & 0.86 \\
\hline S-OW-6.5 & 4.8 & 59 & 0.1 & $4.6 \pm 0.1$ & $1.5 \pm 0.05$ & 25.0 & $22.0 \pm 0.2$ & 36 & 2.7 & 6 & 0.9 & 0.49 \\
\hline F-WC-1 & 18.7 & 67 & 8.8 & $2.7 \pm 0.1$ & $0.5 \pm 0.02$ & 15.3 & $33.1 \pm 1.0$ & 23 & 31.5 & 3.9 & 3.4 & 4.27 \\
\hline F-OW-2 & 17.6 & 67 & 8.6 & $2.8 \pm 0.1$ & $0.3 \pm 0.02$ & 10.1 & $32.6 \pm 0.8$ & 20 & 8.9 & 3.9 & 3.0 & 0.13 \\
\hline O-WC-4 & 17.4 & 26 & 8.7 & $5.2 \pm 2.6$ & $0.5 \pm 0.11$ & 8.9 & $18.8 \pm 0.3$ & 13 & 0.9 & 4.3 & 2.1 & 0.80 \\
\hline O-WC-9 & 8.5 & 30 & 4.7 & $3.4 \pm 0.1$ & $0.5 \pm 0.04$ & 12.1 & $17.1 \pm 0.0$ & 19 & 0.9 & 4.6 & 2.4 & 0.28 \\
\hline O-OW-10 & 8.6 & 30 & 0.8 & $6.3 \pm 0.1$ & $0.5 \pm 0.01$ & 7.9 & $16.7 \pm 1.4$ & 14 & 0.0 & 4.8 & 2.3 & 0.26 \\
\hline STR-WC-1 & 16.4 & 140.1 & 8.5 & ND & ND & ND & $18.8 \pm 0.6$ & 34 & 10.8 & 3.2 & 4.7 & 1.63 \\
\hline STR-OW-2.5 & 16.4 & 285 & 0.3 & ND & ND & ND & $19.6 \pm 0.6$ & 60 & 13.1 & 3 & 4.6 & 1.75 \\
\hline V-WC-2 & 19.7 & 338 & 9.8 & $1.2 \pm 0.1$ & $0.2 \pm 0.06$ & 16.5 & $14.9 \pm 2.3$ & 30 & 52.4 & 2.2 & 8.9 & 4.58 \\
\hline V-OW-6 & 18.8 & 502 & 0.1 & $0.9 \pm 0.1$ & $0.3 \pm 0.01$ & 23.0 & $12.3 \pm 0.1$ & 49 & 52.4 & 2.5 & 8.9 & 3.88 \\
\hline VALE-WC-1 & 17.2 & 331 & 8.6 & ND & ND & ND & $13.3 \pm 0.4$ & 77 & 62.8 & 1.5 & 16.2 & 3.18 \\
\hline VALE-OW-4 & 17.2 & 469 & 0.2 & ND & ND & ND & $14.0 \pm 0.3$ & 77 & 57.8 & 1.4 & 16.2 & 3.92 \\
\hline M-WC-1 & 17.8 & 185 & 6.3 & $2.4 \pm 0.2$ & $2.8 \pm 0.30$ & 53.8 & $9.6 \pm 0.5$ & 198 & 171 & 1.7 & 3.5 & 8.12 \\
\hline M-OW-2 & 17.8 & 185 & 6.3 & $1.6 \pm 0.1$ & $2.9 \pm 0.10$ & 64.4 & $9.2 \pm 0.7$ & 185 & 190 & 1.8 & 3.6 & 6.57 \\
\hline LOTS-WC-2 & 18.2 & 207.1 & 9.1 & ND & ND & ND & $11.9 \pm 0.7$ & 21 & 8.6 & 1.8 & 3.8 & 0.75 \\
\hline LOTS-WC-6 & 17.4 & 209.9 & 5.5 & ND & ND & ND & $13.2 \pm 0.7$ & 16 & 7.5 & 1.7 & 3.8 & 0.60 \\
\hline LOTS-OW-7 & 11.5 & 288 & 0.3 & ND & ND & ND & $13.3 \pm 0.7$ & 65 & 18.1 & 1.7 & 1.6 & 0.61 \\
\hline
\end{tabular}

alkanes C22-24 known to originate from the pyrolysis of resistant bio-macromolecules such as fungal/animal chitin (for example, acetamidofuran) and plant cutin/suberin or algaenan ${ }^{28}$, had also negative loadings on PC2 (Fig. 1a). In contrast, pyrolytic products of high-molecular mass carbohydrates or polysaccharides (that is, levosugars ${ }^{22}$ ) and of long-chain cell wall lipids (that is, $n$-alkanes C27-C29 and alkan-2-ones C29-C33) deriving from plant material, and known to be available for bacterial communities $^{21}$, had positive loadings on PC1.

The studied lakes exhibited a large variation in OM molecular composition as demonstrated by the scatter of sediment samples within the ordination space (Fig. 1b). Sediments from Lötsjön (LOTS), Marnästjärn (M), Strandsjön (STR), Vallentunasjön (VALE) and Valloxen (V) were dominated by autochthonous OM (positive scores on PC1). Whereas LOTS, $\mathrm{M}$, VALE and $\mathrm{V}$ were rich in fresh phytoplankton-derived OM (proteins, chlorophyll), STR contained high proportions of chitin-derived and nitrogen containing organic compounds arising with degradation processes of chlorophyll and proteins (negative scores on PC2) (Fig. 1b). This suggests high invertebrate presence in STR as reported elsewhere ${ }^{29}$, and more extensively degraded sedimentary phytoplankton-derived OM in comparison to the other 4 lakes dominated by autochthonous OM. On the other hand, sediments from Svarttjärn (S), Ljustjärn (LJU), Lilla Sångaren (LS), Oppsveten (O) and Fälaren (F) were dominated by allochthonous $\mathrm{OM}$ of terrestrial origin (negative scores on PC1). More specifically, S and LJU were enriched in recently produced plant-derived OM compounds (positive scores on PC2) while LS and O contained degraded OM compounds (negative scores on PC2). The molecular composition of OM in $\mathrm{F}$ sediments was not well explained by either of the two principal components (low PC-scores; Fig. 1b) but featured high proportions of lignin- and phenolic-derived compounds, indicative of plant-derived OM, and low proportions of proteins and chlorophyll (Supplementary Table 3). The molecular composition of $\mathrm{OM}$ in these sediments thus indicates dominance of terrigenous $\mathrm{OM}$ but with a composition that differs from S, LJU, LS and O. It is noteworthy that the two sediment depth layers $(0-1$ and $1-2 \mathrm{~cm})$ from each individual lake plotted close to each other (Fig. 1b) within the PCA ordination space. Indeed we did not find a clear pattern for organic compounds known to be rapidly degraded (that is, levosugars ${ }^{22}$; chlorophylls ${ }^{24}$ and proteins ${ }^{30}$ ) (Supplementary Table 4) between the two sediment depth layers, implying homogeneity of sedimentary OM molecular composition within the top two $\mathrm{cm}$ of the studied boreal lake sediments.

Predicting $\mathrm{Hg}$ methylation with $\mathrm{OM}$ molecular composition. Potential $\mathrm{Hg}$ methylation and $\mathrm{MeHg}$ demethylation rate constants were determined in sediments using enriched isotope tracers 
a

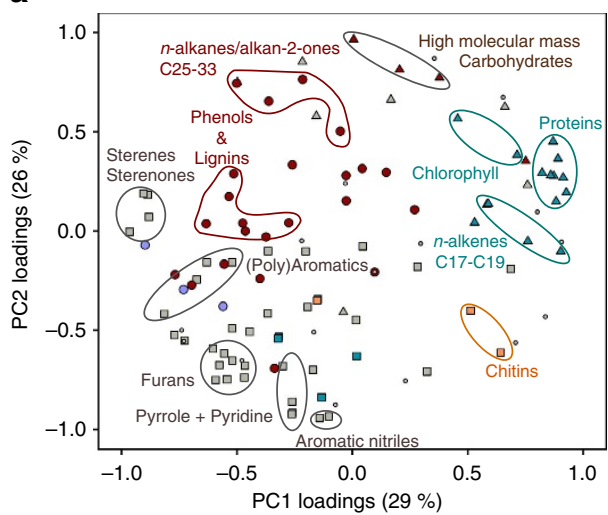

C

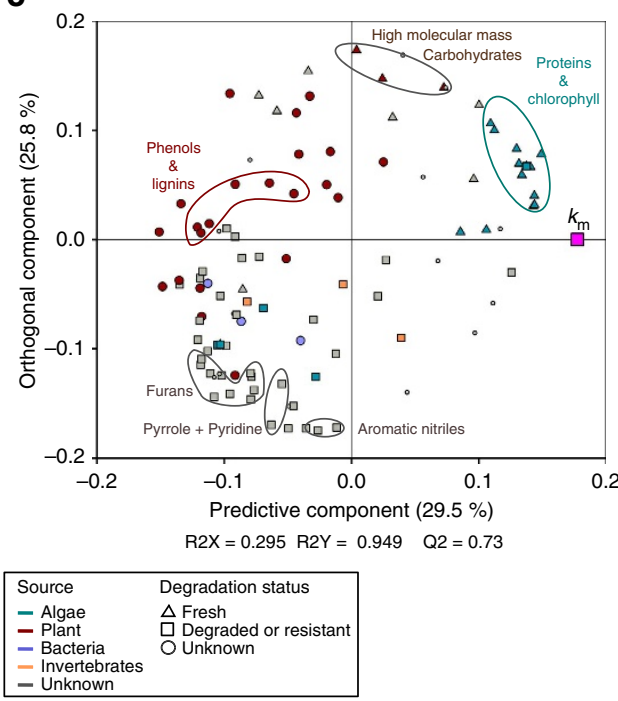

b

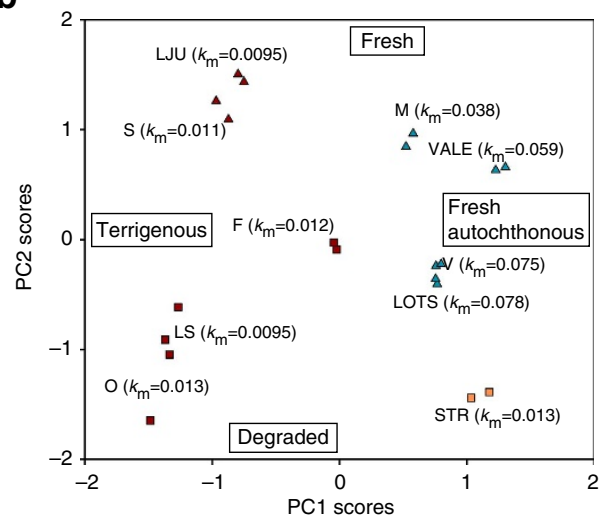

d

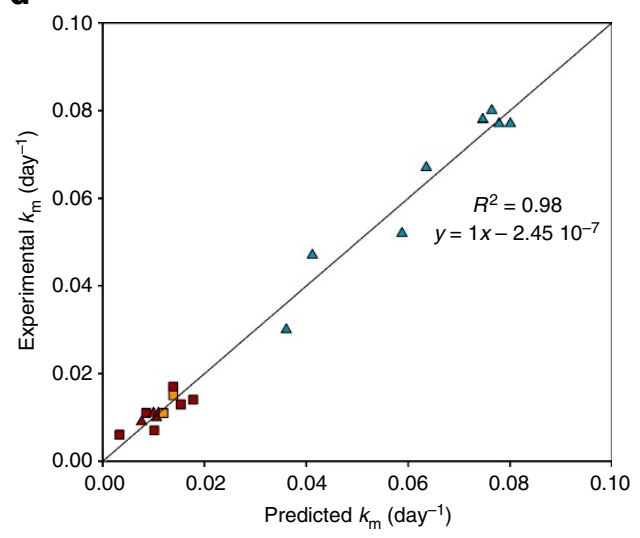

Figure 1 | OM molecular composition and $\mathbf{H g}$ methylation rate constants. PCA $(\mathbf{a}, \mathbf{b})$ and orthogonal projections to latent structures statistical model (OPLS) for $k_{m}(\mathbf{c}, \mathbf{d})$. The pyrolytic organic compounds were sorted out into five categories according to their origin: algae, plant, bacteria, invertebrate or unknown); and three categories according to degradation status: fresh, degraded or unknown (for example, gray circles correspond to compounds with unknown origin (that is, gray) and unknown degradation status (that is, circle)). (a) PC1/2-loadings (b) PC1/2-scores and Hg methylation rate constants $\left(k_{m}\right)(\mathbf{c})$ loadings of OM compounds with a predictive (predictive component) and not predictive capacity (orthogonal component) of the OPLS model for $k_{\mathrm{m}}(\mathbf{d})$ experimental $k_{\mathrm{m}}$ values versus $k_{\mathrm{m}}$ values predicted by the OPLS modelling.

(Supplementary Table 2). Hg methylation rate constants $\left(k_{\mathrm{m}}\right)$ were highest in lakes where the OM was dominated by fresh phytoplankton-derived compounds (LOTS, M, VALE and V; 0.038-0.075 day $^{-1}$, Fig. 1b). Methylation rate constants were dramatically lower in sediments that were either enriched in terrigenous compounds (S, LJU, LS, O and F; 0.0095-0.013 day ${ }^{-1}$ ) or in sediments with high contributions of invertebrate chitin and degraded phytoplankton-derived residues (STR; $0.013 \mathrm{day}^{-1}$ ). An orthogonal projections to latent structures (OPLS, model I) statistical model was developed to explain and predict $k_{\mathrm{m}}$ from the detailed molecular composition of sediment OM (Fig. 1c). OPLS is a recent modification to the PLS regression analysis method that separates the systematic variation of the OM molecular composition $(X)$ into two types of components, that is, predictive components which are linearly related to $Y$ (here $k_{\mathrm{m}}$ ) and orthogonal components to $Y\left(k_{\mathrm{m}}\right)^{31}$. Accordingly, the predictive component of the OPLS model I represents the compounds directly correlating with $k_{\mathrm{m}}$ whereas the orthogonal component denotes the compounds that are not related to $k_{\mathrm{m}}$. The $R^{2} X$ value indicates the proportion of variance in the $X$ variables (that is, the pyrolytic organic compounds) explained by the model, while the $R^{2} Y$ value indicates the proportion of variance in $k_{\mathrm{m}}$ explained by the model. With one predictive component $\left(R^{2} X=29.5 \%\right), \mathrm{Hg}$ methylation rate constants $\left(k_{\mathrm{m}}\right)$ were remarkably well explained $\left(R^{2} Y=95 \%\right)$ and predicted $\left(Q^{2}=78 \%\right)$ by the OPLS model I (Fig. 1c,d). This very high explanatory and predictive power demonstrates that $\mathrm{Hg}$ methylation rate constants can be quantitatively predicted from the molecular composition of sediment OM even in complex systems such as natural boreal lake sediments. The 10 compounds with the highest positive weight on the predictive component originate from fresh chlorophylls (phytene and phytol), proteins (aminopropanoyl leucine and 4 different diketodipiperazines) and phytoplankton-derived cell wall lipids (n-alkenes C20, C17 and C19) (Fig. 1c). In contrast, degraded OM and plant-derived compounds including fresh carbohydrates have either a negative weight on the predictive component or are part of the orthogonal component (O1: $R^{2} X=25.8 \%$; Fig. 1c). Our results therefore show that while plant-derived OM correlates negatively with $\mathrm{Hg}$ methylation, phytoplankton-derived $\mathrm{OM}$ compounds correlate strongly and positively with $\mathrm{Hg}$ methylation rate constants in boreal lake sediments.

Bacterial production rate (BP, $\mu \mathrm{g} \mathrm{Cl}^{-1} \mathrm{~d}^{-1}$ ) was significantly higher in lake sediments with OM of mainly autochthonous 
origin (LOTS, M, VALE, $\mathrm{V}$ and STR, $P$ value $<0.001$ ). Compared with terrigenous $\mathrm{OM}$, autochthonous carbon compounds are known to be preferentially used by heterotrophic bacteria ${ }^{32}$. Hence our results suggest that the OM molecular composition controls bacterial activity and thereby $\mathrm{Hg}$ methylation rates as both of these parameters are enhanced by phytoplankton-derived compounds. Indeed, a second OPLS model (model II, Supplementary Fig. 1) built with both $k_{\mathrm{m}}$ and $\mathrm{BP}$ as $\mathrm{Y}$ variables showed that the abundance of phytoplankton-derived compounds (chlorophyll, protein, cell wall lipids) predicted the variability in both $k_{\mathrm{m}}$ and BP (Supplementary Fig. 1). Furthermore, the second predictive component in this model suggested that among the phytoplankton-derived compounds, Hg methylation rate constants would be higher in the presence of fresh chlorophyll compounds and cell wall lipids, whereas BP was more strongly coupled to $\mathrm{N}$-containing compounds derived from processed chlorophylls and proteins (that is, indole, methyl indole and maleimide) and from microbial chitin (that is, acetamidofuran and oxazoline). The OPLS model II shows therefore that the bacterial activity is well explained $\left(R^{2} Y=96 \%\right)$ and can be well predicted $\left(Q^{2}=86 \%\right)$ by sediment OM molecular composition (Supplementary Fig. 1). In addition to the molecular composition of OM, a positive correlation between temperature of the water overlying the sediments and the presence of phytoplankton-derived OM (Fig. 3), and the sediment BP $(P$-value $=0.041)$, suggested a positive effect of temperature on phytoplankton-derived $\mathrm{OM}$ production and therefore on $\mathrm{Hg}$ methylation rates. Indeed, lakes dominated by phytoplankton-derived OM were warmer (Table 1) and shallower (Table 2) than those characterized by terrigenous OM inputs. The effect of environmental factors such as temperature, redox and concentrations of iron and sulfur on $\mathrm{Hg}$ methylation processes has been addressed previously 13,33,34. For example, Korthals and Winfrey ${ }^{33}$ showed that while temperature could explain $30 \%$ of the seasonal variation in $\mathrm{Hg}$ methylation in one specific lake, the variation in $\mathrm{Hg}$ methylation between sites was not significantly correlated to in situ temperature of different lakes. Drott et al. ${ }^{13}$ showed that sulfide concentration can modulate the differences in $k_{\mathrm{m}}$ at different sediment depths of an aquatic system, but the 'quality of OM' assessed by the $\mathrm{C} / \mathrm{N}$ ratio defined the differences observed in $k_{\mathrm{m}}$ between different sites. We thus conclude that OM molecular composition is the primary factor determining differences in BP and $k_{\mathrm{m}}$ across boreal lakes.

Compared with the OPLS model I, BP as a single variable only explained $73 \%$ of the variation in $\mathrm{Hg}$ methylation rate (Fig. 2a) while $95 \%$ of the variance was explained by the OM molecular composition. This implies that besides the general stimulation of BP by phytoplankton-derived compounds, certain OM molecules are likely to specifically stimulate methylating bacterial populations and/or modulate $\mathrm{Hg}$ availability. There are currently no techniques for determining the concentration of Hg-complexes available for bacterial uptake in sediments. However the few studies that have assessed the role of different OM fractions on $\mathrm{Hg}$ availability for methylating bacteria in laboratory experiments ${ }^{8,35-37}$ have highlighted a strong influence of low molecular mass thiols on bacterial $\mathrm{Hg}$ uptake ${ }^{8,35}$. Moreover, it has been suggested that algal and cyanobacterial exudates that contain low molecular mass thiols can enhance $k_{\mathrm{m}}$ in periphytic biofilms ${ }^{16}$. The high $k_{\mathrm{m}}$ observed in the sediments rich in phytoplanktonderived OM could be explained by a combined effect of enhanced activity of the microbial community, as bacterial communities preferentially use algal-derived OM for respiration ${ }^{38}$, and a higher abundance of low molecular mass thiols derived from phytoplankton-derived exudates ${ }^{16}$.

Linking OM molecular composition with bulk parameters and Hg methylation. Conventional bulk parameters such as THg,

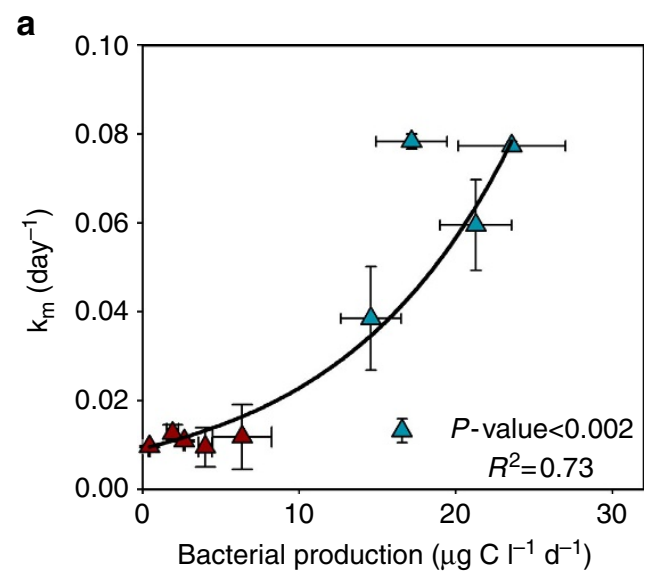

b

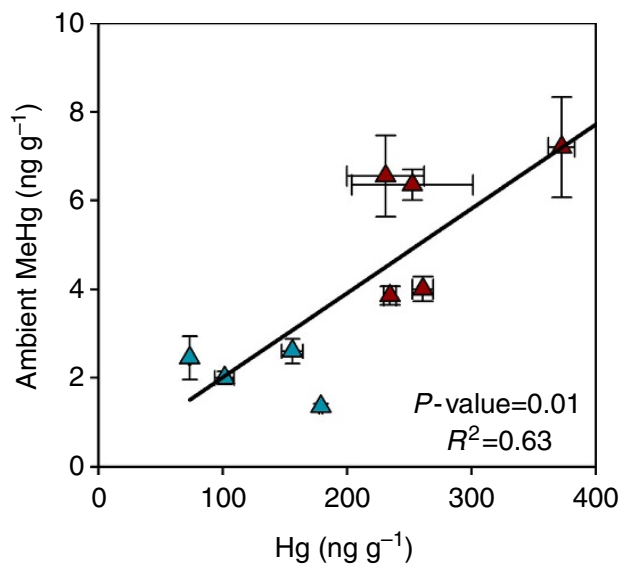

C

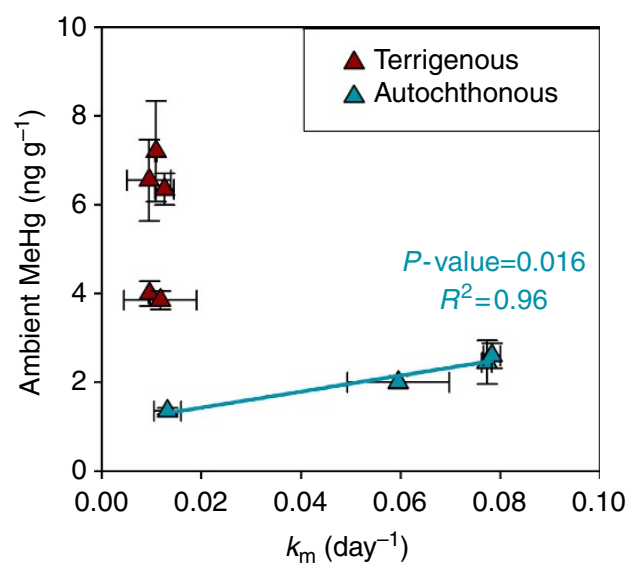

Figure 2 | Relationships between $\mathrm{Hg}$ parameters and bacterial production for lakes dominated by autochthonous versus terrigenous OM. Relationship between (a) $\mathrm{Hg}$ methylation rate constant $\left(k_{\mathrm{m}}\right.$ in day $\left.{ }^{-1}\right)$ and bacterial production, (b) concentration of inorganic $\mathrm{Hg}\left(\mathrm{ng} \mathrm{g}^{-1}\right)$ and $\mathrm{MeHg}$ concentration ( $\mathrm{ng} \mathrm{g}^{-1}$ ) and (c) $\mathrm{Hg}$ methylation rate constant and $\mathrm{MeHg}$ concentration ( $\mathrm{ng} \mathrm{g}^{-1}$ ). The lake sediments dominated by terrigenous allochthonous OM (Lilla Sångaren, Ljustjärn, Svarttjärn, Fälaren, Oppsveten) are represented with red triangles. Lake sediments dominated by autochthonous OM (Strandsjön, Valloxen, Vallentunasjön, Marnästjärn and Lötsjön) are represented by green triangles. The lake Marnästjärn which is highly contaminated by historical anthropogenic inputs of $\mathrm{Hg}$ was not included in chart c. Error bars represent one standard deviation. 


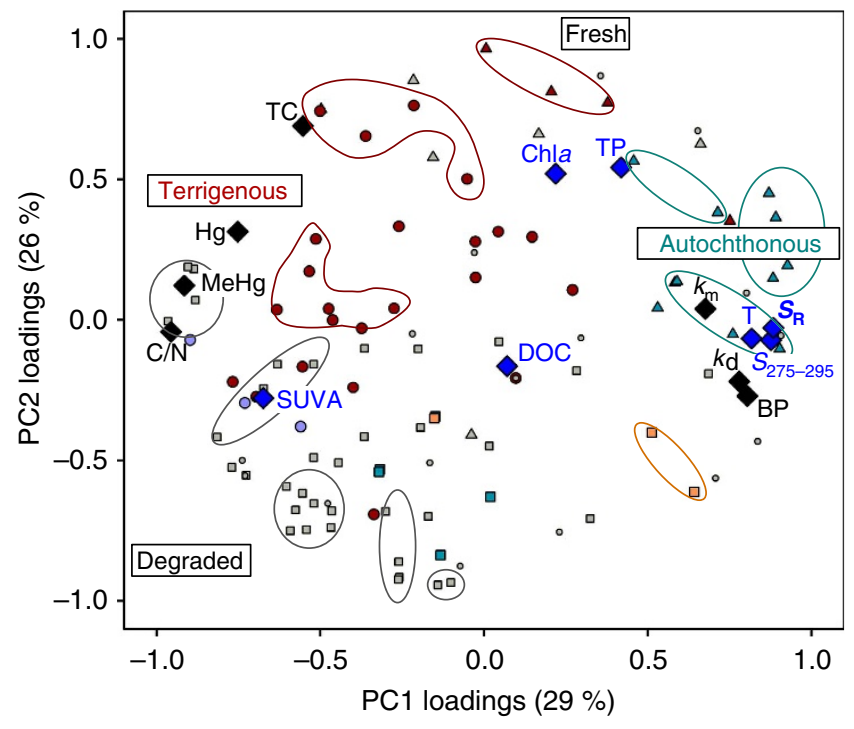

Source - Algae - Plant - Bacteria - Invertebrates - Unknown Degradation status $\triangle$ Fresh $\square$ Degraded or resistant $O$ Unknown

Figure 3 | Comparison of bulk parameters and OM composition.

Correlation analyses between conventional parameters (diamonds) measured in sediments (black) and their overlying water (blue) with the two first components of the PCA used to describe sediment

OM molecular composition variation in the 10 studied boreal lakes.

Similarly to Fig. 1, PC1/2-loadings of the pyrolytic organic compounds are sorted out into according to their origin (algal, plant, bacteria, invertebrate or unknown) and to their degradation status (fresh, degraded or unknown).

$\mathrm{MeHg}$, DOC, TP, $\mathrm{O}_{2}$, sulphate concentrations and optical properties were measured in a vertical profile of each water column (Table 2; Supplementary Table 1). Total C, TP, total N, C/N ratio and bacterial production rate (BP) were determined at two sediment depths $(0-1$ and $1-2 \mathrm{~cm}$ ) for each lake (Supplementary Table 2). The comparison of sediment OM molecular composition with conventional OM parameters measured in sediments and in water overlying the sediment was carried out by reporting the correlation coefficients between these latter parameters and the scores of the two first principal components of the PCA (Fig. 3). The results confirm that high chlorophyll $a(\mathrm{chl} a)$ and TP concentrations (common proxies for autochthonous production) in water overlying the sediment correlate with the presence of phytoplankton-derived $\mathrm{OM}$ in surface sediments. In contrast, $\mathrm{SUVA}_{254}$, a traditional indicator of aromaticity ${ }^{39}$, was positively correlated with (poly)aromatic pyrolytic compounds coming from terrestrial inputs (negative loadings on PC1). Therefore, conventional bulk OM parameters measured in water overlying the sediment reflected well the sediment OM molecular composition in terms of OM sources. In contrast, our results also indicate that DOC was not strongly coupled to any particular source of $\mathrm{OM}$. The total $\mathrm{C}, \mathrm{Hg}$ and $\mathrm{MeHg}$ in sediments were positively correlated with terrigenous $\mathrm{OM}$ compounds (negative loadings on $\mathrm{PC} 1$ ). The $\mathrm{C} / \mathrm{N}$ ratio, previously suggested as a reliable proxy for the lability of OM modulating $\mathrm{Hg}$ methylation rates ${ }^{13}$, was rather correlated with the presence of pyrolytic compounds derived from more extensively degraded terrigenous OM (negative loadings on PC1). While previous studies have reported low $\mathrm{Hg}$ methylation rates in sediments with high $\mathrm{C} / \mathrm{N}$ ratio ${ }^{13,14}$, our results demonstrate that lake sediments with low $\mathrm{C} / \mathrm{N}$ ratios but that are enriched in chitin compounds derived from degraded planktonic OM (for example, STR) feature low $\mathrm{Hg}$ methylation rates (Fig. 1b). Hence the measurement of bulk parameters such as chl $a$ concentration or $\mathrm{C} /$
$\mathrm{N}$ ratio can be useful to determine specific groups of organic compounds but fails at describing OM composition in the system. A detailed characterization of $\mathrm{OM}$ molecular composition is therefore required to disentangle the combined effects of different $\mathrm{OM}$ compounds on $\mathrm{Hg}$ methylation and to obtain precise and robust predictions of $\mathrm{Hg}$ methylation rates in boreal lake sediments.

MeHg sources for boreal lakes. To further describe the implications of $\mathrm{OM}$ molecular composition on $\mathrm{MeHg}$ cycling in boreal lakes, we investigated the relationship between in situ $\mathrm{Hg}$ methylation rate constants and sediment $\mathrm{MeHg}$ concentration in the two types of lake sediments, that is, sediments rich in autochthonous or in terrigenous OM. In lake sediments, the concentration of $\mathrm{MeHg}$ is determined by the $\mathrm{Hg}$ methylation rate $\left(k_{\mathrm{m}} \times[\mathrm{Hg}]\right)$ and $\mathrm{MeHg}$ demethylation rate $\left(k_{\mathrm{d}} \times[\mathrm{MeHg}]\right)$ and by $\mathrm{MeHg}$ import and export from the system $^{40}$. While lake sediments dominated by terrigenous $\mathrm{OM}$ presented lower $\mathrm{Hg}$ methylation and $\mathrm{MeHg}$ demethylation rate constants than lakes enriched in phytoplankton-derived OM (Fig. 2b), they featured significantly higher $\mathrm{Hg} \quad(P$-value $=0.006)$ and $\mathrm{MeHg}$ concentrations $(P$-value $=0.004)$. High $\mathrm{MeHg}$ concentrations and decoupling of $\mathrm{MeHg}$ and either $\mathrm{Hg}$ methylation rate constants (Fig. 2c) or $k_{\mathrm{m}} k_{\mathrm{d}}^{-1}$ ratios (Supplementary Fig. 3a) in sediments dominated by terrigenous OM, suggest that $\mathrm{MeHg}$ levels in such sediments are most likely controlled by import of $\mathrm{MeHg}$ originally produced in the catchment and subsequently transported to lake sediments by surface runoff and other hydrological processes (Fig. 4b). Indeed, the correlations between terrestrially derived $\mathrm{OM}$ and concentrations of both $\mathrm{Hg}$ and $\mathrm{MeHg}$ (Fig. 3) points to catchment inputs of terrigenous $\mathrm{Hg}$ and $\mathrm{MeHg}$. This is plausible considering that a large pool of $\mathrm{Hg}$ have accumulated in Swedish soils following atmospheric deposition during the industrial $\mathrm{era}^{41}$ and that, recently, an increased released of DOC from soils to lakes has been linked to a two-fold increase in $\mathrm{Hg}$ in sediments ${ }^{42}$. By linking a detailed characterization of sediment OM molecular composition with $\mathrm{Hg}$ and $\mathrm{MeHg}$ transformation potentials, our study points to catchment inputs of terrigenous $\mathrm{OM}$ as the main source of $\mathrm{Hg}$ and $\mathrm{MeHg}$ for boreal lakes dominated by allochthonous OM.

In contrast, for lake sediments enriched in autochthonous phytoplankton-derived OM, the concentration of $\mathrm{MeHg}$ was positively correlated to the $\mathrm{Hg}$ methylation rate constant (Fig. 2c), the percentage of ambient $\mathrm{MeHg}$ (Supplementary Fig. 2b) and the $k_{\mathrm{m}} k_{\mathrm{d}}^{-1}$ ratio (Supplementary Fig. 3a). The latter two have often been used as proxies for net $\mathrm{Hg}$ methylation ${ }^{43}$. These correlations indicated that in situ $\mathrm{Hg}$ methylation determines $\mathrm{MeHg}$ levels in boreal lakes dominated by autochthonous phytoplanktonderived OM. Moreover, the OM molecular composition of lake sediments dominated by autochthonous OM showed that inputs from the boreal forest catchments were minor (Supplementary Table 3). With low Hg inputs from the catchment, atmospheric $\mathrm{Hg}$ deposition, which is similar for all the studied lakes ${ }^{44}$, may thus be the primary source of $\mathrm{Hg}$ to lakes dominated by autochthonous OM (Fig. 4a). We conclude that processes determining $\mathrm{MeHg}$ concentrations in lakes dominated by phytoplankton-derived OM are different from those in lakes enriched in terrigenous OM (Fig. 4). While sediment $\mathrm{MeHg}$ in boreal lakes dominated by autochthonous OM inputs is mainly produced within the system, allochthonous $\mathrm{MeHg}$ formed in the surrounding catchment is likely the main source of $\mathrm{MeHg}$ for boreal lake sediments enriched in terrigenous OM.

\section{Discussion}

By using a sophisticated characterization of OM, we show for the first time that the molecular composition of OM is an important 

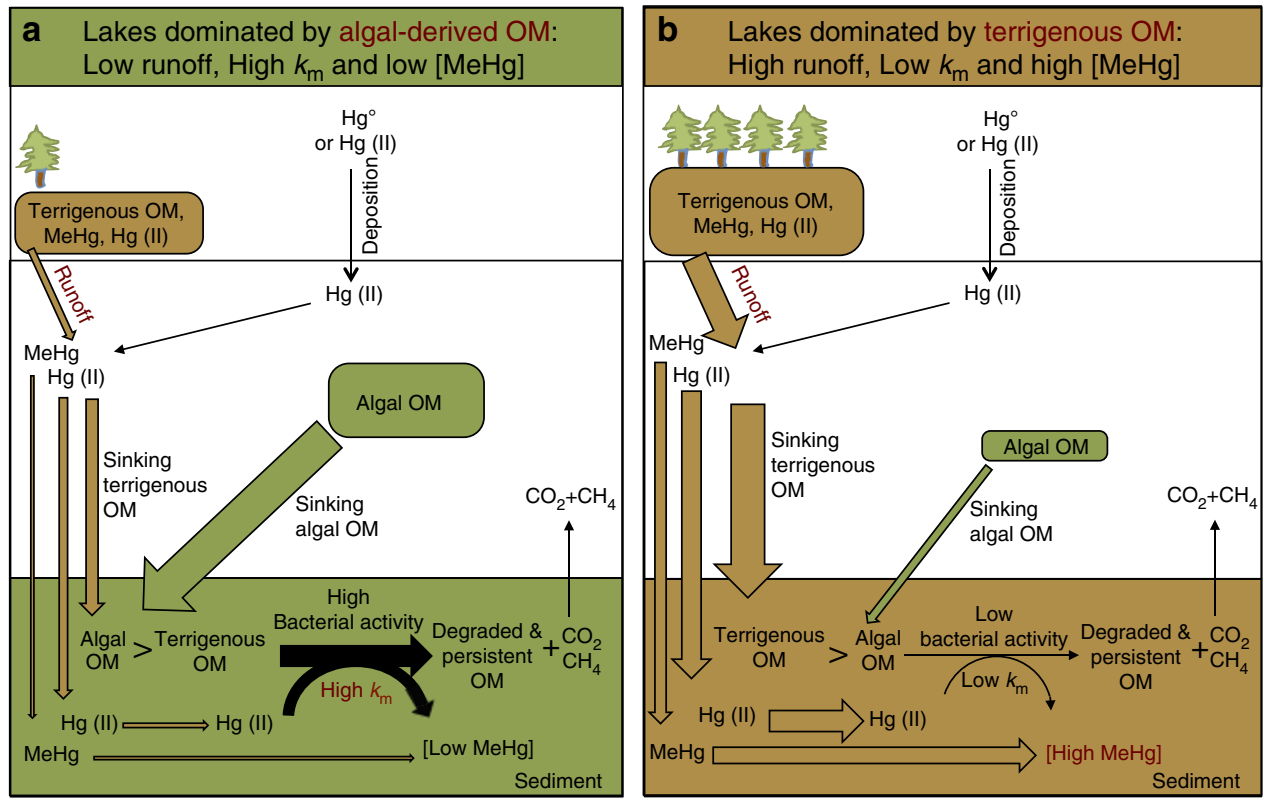

Figure 4 | Conceptual model of MeHg sources for lake sediments. (a) Lakes with high occurrence of planktonic blooms are enriched in fresh chlorophylls and proteins that enhance bacterial activity and $\mathrm{MeHg}$ formation; (b) increased runoff of terrigenous $\mathrm{OM}$ brings large amounts of $\mathrm{Hg}$ and $\mathrm{MeHg}$ but hampers in situ MeHg formation. MeHg in eutrophic lakes is the result of in situ production whereas runoff is the main source of MeHg for lakes dominated by terrigenous $\mathrm{OM}$.

factor controlling the formation of neurotoxic $\mathrm{MeHg}$ in sediments and we provide insightful information to pinpoint the sources of $\mathrm{Hg}$ and $\mathrm{MeHg}$ in lake ecosystems. Based on our results and preceding work, we provide an updated framework for understanding and predicting $\mathrm{MeHg}$ concentration in boreal lake sediments (Fig. 4). We predict that enhanced phytoplankton blooms would likely cause increased $\mathrm{Hg}$ methylation rates and thus lead to higher $\mathrm{MeHg}$ levels in boreal lake sediments that receive low inputs of terrigenous OM (Fig. 4a). Also, increased import of terrigenous OM from surrounding catchments, for example, due to on-going climate change ${ }^{45}$, may lead to higher $\mathrm{MeHg}$ concentrations in boreal lake sediments (Fig. 4b). In a global context of projected higher frequency of algal blooms caused by eutrophication ${ }^{46}$ and increased global inputs of terrigenous organic matter to freshwater ecosystems ${ }^{45}$, our findings bring new perspectives on how such future environmental changes may alter the biogeochemical cycling of $\mathrm{Hg}$ in boreal areas. Future studies are nevertheless needed to develop this framework further by including other environmental factors such as $\mathrm{pH}$, redox and sulfur geochemistry known to modulate $\mathrm{Hg}$ availability and/or the activity of $\mathrm{Hg}$ methylating microorganisms; by considering also the bioaccumulation/ biomagnification processes; and by extending it to other aquatic ecosystems such as alpine lakes, ponds, rivers, estuaries and sea.

\section{Methods}

Site selection and sampling. We surveyed 10 lakes in central Sweden with different trophic status and receiving different amounts of terrigenous OM (Tables 1 and 2). We carried out two sampling campaigns: samples from $\mathrm{M}$, and V, S, LS, O and F were retrieved in July 2012 and samples from LOTS, VALE, STR, LJU were collected in July 2013. Water column samples were collected with a GoFlo bottle (PVC). For $\mathrm{Hg}$ and $\mathrm{MeHg}$ measurements, 11 of unfiltered water was placed in Teflon bottles and acidified $(1 \% \mathrm{v} / \mathrm{v}$ final concentration; $\mathrm{HCl}$ Ultrex II, J. T. Baker). Within each lake, intact sediment cores with about $30 \mathrm{~cm}$ of overlying water were sampled with a $6-\mathrm{cm}$ diameter gravity corer (UWITEC, Austria). After sampling, cores were kept upright at $4^{\circ} \mathrm{C}$ with about $40 \mathrm{~cm}$ of overlying water until further processing within $12 \mathrm{~h}$. All the steps involved in sediment handling and treatments were carried out in a $\mathrm{N}_{2}$-filled glove box (Sigma-Aldrich, USA) to prevent oxidation of reduced chemical species. Sediment overlying water was first retrieved with acid-washed syringes from the sediment cores and then the upper $2 \mathrm{~cm}$ of the sediment core $(0-1$ and $1-2 \mathrm{~cm}$ ) were sliced using acid washed plastic tools and used for further incubations or analyses. Sediment overlying waters were filtered through glass fiber filters (Whatmann, GF/F) and analysed for sulphate, DOC, TP, chlorophyll and optical OM properties (Supplementary Table 1). The remaining solid sediments were used for quantification of $\mathrm{THg}, \mathrm{MeHg}$ and $\mathrm{C}, \mathrm{N}, \mathrm{P}$ concentrations, bacterial activity and $\mathrm{Hg}$ methylation $\left(k_{\mathrm{m}}\right)$ and demethylation $\left(k_{\mathrm{d}}\right)$ rates (Supplementary Table 2$)$ and OM characterization (Supplementary Table 3 ).

Water characteristics. For optical characterization of OM in sediment overlying water, the absorbance spectra $(200-800 \mathrm{~nm})$ were measured with a Lambda 40 spectrophotometer (Perkin-Elmer, Waltham, USA). Spectral slope of absorbance coefficients between 275 and 295, and 350 and $400 \mathrm{~nm}$, were obtained by non-linear fitting of the exponential model: $a_{\lambda}=a_{\lambda_{0}} e^{\mathrm{S}(\lambda-\lambda)}$ where $\lambda_{0}>\lambda$ and $S$ is the spectral slope in the $\lambda_{0}-\lambda$ spectral range ${ }^{47-49}$. The slope ratio, $S_{\mathrm{R}}$, resulted from the ratio between $S_{275-295} \mathrm{~nm}$ and $S_{350-400} \mathrm{~nm}$ (ref. 48). We used the optical index $\left(\mathrm{SUVA}_{254}\right)$, which is related to the aromaticity, to compare our data with those from the literature ${ }^{36}$. The concentration of TP in the water was determined according to Murphy et al. ${ }^{50}$ The DOC content from the water column was measured by high temperature catalytic oxidation (Shimadzu-TOC-L) ${ }^{51}$. $\mathrm{SUVA}_{254}$ values were not corrected for iron concentrations.

Sediment properties. For measurements of total carbon and nitrogen concentrations about 7-10 mg of sediment were analysed by high-temperature catalytic oxidation with COTECH ECS 4010 elemental analyzer calibrated with sulfanilamide standard (C 41.84\%, N 16.27\%, H 4.68\%, O $18.58 \%$, S 18.62\%). Analytical precision was $< \pm 0.4 \%$ for $\mathrm{C}$ and $\pm 2.1 \%$ for N. TP in sediments was measured as molybdate reactive phosphorus according to an established method ${ }^{50}$ Measurement of chlorophyll- $a$ from phytoplankton was performed using ethanol as extraction solvent ${ }^{52}$. Bacterial production was measured after $1 \mathrm{~h}$ incubation at in situ temperature with $3 \mathrm{H}$-labelled thymidine (Amersham, $1 \mathrm{mCi} \mathrm{ml}^{-1}$, $80 \mathrm{Ci} \mathrm{mmol}^{-1}$ ), at a final concentration of $12 \mathrm{nM}$ (ref. 53). Leucine incorporation into protein was determined by precipitation with TCA and centrifugation, followed by scintillation counting with a Packard Tri-Carb 2100 TR liquid scintillation analyzer (PerkinElmer Life Sciences, Inc., Boston, USA). The leucine incorporation was converted into carbon units according to Simon and Azam ${ }^{53}$. 
Hg analyses. Potential rate constants for $\mathrm{Hg}$ methylation and $\mathrm{MeHg}$ demethylation were assayed by incubating the sliced sediments in sealed glass vials under dark and in situ temperature for $24 \mathrm{~h}$ with ${ }^{198} \mathrm{Hg}^{2+}$ and ${ }^{204} \mathrm{Hg}-\mathrm{CH}_{3}$ isotope tracers added close to ambient concentrations. Hg species were extracted from the sediments by an acidic extraction assisted by microwave and then analysed by species specific isotope dilution and capillary gas chromatography hyphenated to inductively coupled plasma mass spectrometer (GC-ICPMS) ${ }^{54}$.

Molecular OM characterization. Sedimentary OM composition was characterized using an oven pyrolyser equipped with an autosampler (PY-2020iD and AS-1020E, FrontierLabs, Japan) and connected to a GC/MS system (Agilent, 7890A-5975C, Agilent Technologies AB, Sweden), following the operating conditions optimized by Tolu et al. ${ }^{20}$. A data processing pipeline was employed to automatically integrate the peaks and extract the corresponding mass spectra under ' $R$ ' computational environment (version 2.15.2, 64 bits; http://www.R-projector.org). The compounds associated to the extracted mass spectra were identified under 'NIST MS Search 2' software using 'NIST/EPA/NIH 2011' library (http://chemdata.nist.gov/dokuwiki/doku.php?id=chemdata: ms-search) and additional published spectra. The 110 identified pyrolytic compounds are presented in Supplementary Table 5 with information about their origin and degradation status according to the literature review given in Tolu et al. ${ }^{20}$. For each sample, peak areas of the identified compounds were normalized to $100 \%$.

Statistical analyses. Distributional properties of the data and transformations required to meet assumptions of normality (for example, $1 / k_{\mathrm{m}}$ ) were checked before the analysis of the data. The homogeneity in the variances was tested using the Levene test. Pearson correlations were used to test relationships between $\mathrm{Hg}$ methylation rate constants and conventional geochemical parameters. Regression analyses were carried out to evaluate relationships between $\mathrm{BP}, k_{\mathrm{m}}$, $\mathrm{MeHg}$ concentrations, \%MeHg/THg and $k_{\mathrm{m}} k_{\mathrm{d}}^{-1}$ (Sigmaplot 12). Univariate Analyses of Variance were applied to test for significant differences in the $\mathrm{HgII}, \mathrm{MeHg}$ and $k_{\mathrm{m}}$ between lake groups (autochthonous versus terrigenous) using SPSS software package PASW (version 22.0). PCA were performed with the 110 pyrolytic compounds and the 2 sediment depths for each lake also using SPSS 22.0. The principal components (PCs) were extracted using a Varimax rotated solution. The factor loading coefficients (PC-loadings) were calculated as regression coefficients (Fig. 1a,b). The multivariate calibration model between $\mathrm{Hg}$ methylation rate and bacterial production (variable $Y$ ) and the 110 pyrolytic organic compounds (variables $X$ ) was calculated and cross-validated using OrthogonalPartial Least Square (O-PLS) regression in SIMCA software package, version 13 (Umetrics Umeå, Sweden). The quality of the model is described by $R^{2} Y$ and $Q^{2}$ values. $R^{2} Y$ represents the proportion of variance of the variable $Y$ (Hg methylation rate constants and bacterial production) explained by the model and indicates goodness of fit, while $Q^{2}$ corresponds the proportion of variance in the data predictable by the model and indicates predictability (Fig. 1c,d; Supplementary Fig. 1). Correlations between molecular composition of OM and conventional geochemical parameters (Fig. 3) were determined by principal components regression analysis.

Data availability. All data are presented in the paper as tables in the main manuscript or in the supporting information. Raw data will be provided upon request from the authors.

\section{References}

1. UNEP. Global Mercury Assessment: Sources, Emisssions, Releases and Environmental Transport (UNEP Chemicals Branch, Geneva, Switzerland, 2013).

2. Bellanger, M. et al. Economic benefits of methylmercury exposure control in Europe: monetary value of neurotoxicity prevention. Environ. Health 12, 3 (2013).

3. Gilmour, C. C. et al. Mercury methylation by novel microorganisms from new environments. Environ. Sci. Technol. 47, 11810-11820 (2013).

4. Parks, J. M. et al. The genetic basis for bacterial mercury methylation. Science 339, 1332-1335 (2013).

5. Sunderland, E. M. et al. Speciation and bioavailability of mercury in well-mixed estuarine sediments. Mar. Chem. 90, 91-105 (2004).

6. Eckley, C. S. \& Hintelmann, H. Determination of mercury methylation potentials in the water column of lakes across Canada. Sci. Total Environ. 368, 111-125 (2006).

7. Ullrich, S. M., Tanton, T. W., Abdrashitova, S. A. \& Svetlana, A. Mercury in the aquatic environment: a review of factors affecting methylation. Crit. Rev. Environ. Sci. Technol. 31, 241-293 (2001).

8. Schaefer, J. K. \& Morel, F. M. M. High methylation rates of mercury bound to cysteine by Geobacter sulfurreducens. Nat. Geosci. 2, 123-126 (2009).
9. Kothawala, D. N. et al. Controls of dissolved organic matter quality: evidence from a large-scale boreal lake survey. Glob. Chang. Biol. 20, 1101-1114 (2014).

10. Kellerman, A. M., Dittmar, T., Kothawala, D. N. \& Tranvik, L. J. Chemodiversity of dissolved organic matter in lakes driven by climate and hydrology. Nat. Commun. 5, 3804 (2014).

11. Kellerman, A. M., Kothawala, D. N., Dittmar, T. \& Tranvik, L. J. Persistence of dissolved organic matter in lakes related to its molecular characteristics. Nat. Geosci. 8, 454-457 (2015).

12. Schartup, A. T., Mason, R. P., Balcom, P. H., Hollweg, T. A. \& Chen, C. Y. Methylmercury production in estuarine sediments: role of organic matter. Environ. Sci. Technol. 47, 695-700 (2013).

13. Drott, A., Lambertsson, L., Björn, E. \& Skyllberg, U. Importance of dissolved neutral mercury sulfides for methyl mercury production in contaminated sediments. Environ. Sci. Technol. 41, 2270-2276 (2007).

14. Kim, M., Han, S., Gieskes, J. \& Deheyn, D. D. Importance of organic matter lability for monomethylmercury production in sulfate-rich marine sediments. Sci. Total Environ. 409, 778-784 (2011).

15. Lázaro, W. L., Guimarães, J. R. D., Ignácio, A. R. A., Da Silva, C. J. \& Díez, S Cyanobacteria enhance methylmercury production: a hypothesis tested in the periphyton of two lakes in the Pantanal floodplain, Brazil. Sci. Total Environ. 456-457, 231-238 (2013).

16. Leclerc, M., Planas, D. \& Amyot, M. Relationship between extracellular low molecular weight thiols and mercury species in natural lake periphytic biofilms. Environ. Sci. Technol. 49, 7709-7716 (2015).

17. Verpoorter, C., Kutser, T., Seekell, D. A. \& Tranvik, L. J. A global inventory of lakes based on high-resolution satellite imagery. Geophys. Res. Lett. 41, 2014GL060641 (2014).

18. Kortelainen, P., Pajunen, H., Rantakari, M. \& Saarnisto, M. A large carbon pool and small sink in boreal Holocene lake sediments. Glob. Chang. Biol. 10, 1648-1653 (2004).

19. Monteith, D. T. et al. Dissolved organic carbon trends resulting from changes in atmospheric deposition chemistry. Nature 450, 537-540 (2007).

20. Tolu, J., Gerber, L., Boily, J.-F. \& Bindler, R. High-throughput characterization of sediment organic matter by pyrolysis-gas chromatography/mass spectrometry and multivariate curve resolution: a promising analytical tool in (paleo)limnology. Anal. Chim. Acta 880, 93-102 (2015).

21. Meyers, P. A. \& Ishiwatari, R. Lacustrine organic geochemistry - an overview of indicators of organic-matter sources and diagenesis in lake-sediments. Org. Geochem. 20, 867-900 (1993).

22. Schellekens, J., Buurman, P. \& Pontevedra-Pombal, X. Selecting parameters for the environmental interpretation of peat molecular chemistry-a pyrolysis-GC/ MS study. Org. Geochem. 40, 678-691 (2009).

23. Fabbri, D., Adamiano, A., Falini, G., De Marco, R. \& Mancini, I. Analytical pyrolysis of dipeptides containing proline and amino acids with polar side chains. Novel 2,5-diketopiperazine markers in the pyrolysates of proteins. J. Anal. Appl. Pyrolysis 95, 145-155 (2012).

24. Nguyen, R. T. et al. Preservation of algaenan and proteinaceous material during the oxic decay of Botryococcus braunii as revealed by pyrolysis-gas chromatography/mass spectrometry and ${ }^{13} \mathrm{C}$ NMR spectroscopy. Org Geochem. 34, 483-497 (2003).

25. Peulve, S., Sicre, M. A., Saliot, A., De Leeuw, J. W. \& Baas, M. Molecular characterization of suspended and sedimentary organic matter in an Arctic delta. Limnol. Oceanogr. 41, 488-497 (1996).

26. Bianchi, T. S. \& Canuel, E. A. Chemical Biomarkers in Aquatic Ecosystems (Princeton University Press, 2011).

27. Gupta, N. \& Cody, G. Identification and Characterization of Chitin in Organisms (Springer, 2011).

28. Buurman, P. \& Roscoe, R. Different chemical composition of free light, occluded light and extractable SOM fractions in soils of Cerrado and tilled and untilled fields, Minas Gerais, Brazil: a pyrolysis-GC/MS study. Eur. J. Soil Sci. 62, 253-266 (2011).

29. van Hardenbroek, M., Lotter, A. F., Bastviken, D., Andersen, T. J. \& Heiri, O Taxon-specific $\delta^{13} \mathrm{C}$ analysis of chitinous invertebrate remains in sediments from Strandsjön, Sweden. J. Paleolimnol. 52, 95-105 (2014).

30. Knicker, H. Stabilization of N-compounds in soil and organic-matter-rich sediments - what is the difference? Mar. Chem. 92, 167-195 (2004).

31. Trygg, J. \& Wold, S. Orthogonal projections to latent structures (O-PLS). J. Chemom. 16, 119-128 (2002).

32. Kritzberg, E. S., Cole, J. J., Pace, M. L., Granéli, W. \& Bade, D. L. Autochthonous versus allochthonous carbon sources of bacteria: Results from whole-lake ${ }^{13} \mathrm{C}$ addition experiments. Limnol. Oceanogr. 49, 588-596 (2004).

33. Korthals, E. T. \& Winfrey, M. R. Seasonal and spatial variations in mercury methylation and demethylation in an oligotrophic lake. Appl. Environ. Microbiol. 53, 2397-2404 (1987).

34. Bravo, A. G. et al. High methylmercury production under ferruginous conditions in sediments impacted by sewage treatment plant discharges. Water Res. 80, 245-255 (2015). 
35. Schaefer, J. K. et al. Active transport, substrate specificity, and methylation of $\mathrm{Hg}(\mathrm{II})$ in anaerobic bacteria. Proc. Natl Acad. Sci. USA 108, 8714-8719 (2011).

36. Graham, A. M., Aiken, G. R. \& Gilmour, C. C. Effect of dissolved organic matter source and character on microbial $\mathrm{Hg}$ methylation in $\mathrm{Hg}-\mathrm{S}-\mathrm{DOM}$ solutions. Environ. Sci. Technol. 47, 5746-5754 (2013).

37. Moreau, J. W. et al. The effect of natural organic matter on mercury methylation by Desulfobulbus propionicus 1pr3. Front. Microbiol. 6, 1389 (2015).

38. Guillemette, F., McCallister, S. L. \& del Giorgio, P. A. Selective consumption and metabolic allocation of terrestrial and algal carbon determine allochthony in lake bacteria. ISME J. 10, 1373-1382 (2015).

39. Weishaar, J. L. et al. Evaluation of specific ultraviolet absorbance as an indicator of the chemical composition and reactivity of dissolved organic carbon. Environ. Sci. Technol. 37, 4702-4708 (2003).

40. Drott, A., Lambertsson, L., Björn, E. \& Skyllberg, U. Do potential methylation rates reflect accumulated methyl mercury in contaminated sediments? Environ. Sci. Technol. 42, 153-158 (2008)

41. Johansson, K. \& Tyler, G. Impact of atmospheric long range transport of lead, mercury and cadmium on the Swedish forest environment. Water Air Soil Pollut. Focus 1, 279-297 (2001).

42. Isidorova, A. et al. The effect of lake browning and respiration mode on the burial and fate of carbon and mercury in the sediment of two boreal lakes. J. Geophys. Res. Biogeosci. 121, 233-245 (2016).

43. Bravo, A. G. et al. Extremely elevated methyl mercury levels in water, sediment and organisms in a Romanian reservoir affected by release of mercury from a chlor-alkali plant. Water Res. 49, 391-405 (2014).

44. Munthe, J. et al. Mercury in Nordic Ecosystems (IVL Report B1761, 2007).

45. Larsen, S., Andersen, T. \& Hessen, D. O. Climate change predicted to cause severe increase of organic carbon in lakes. Glob. Chang. Biol. 17, 1186-1192 (2011).

46. Bennett, E. M., Carpenter, S. R. \& Caraco, N. F. Human impact on erodable phosphorus and eutrophication: a global perspective. Bioscience 51, 227-234 (2001).

47. Fichot, C. G. \& Benner, R. The spectral slope coefficient of chromophoric dissolved organic matter (S275-295) as a tracer of terrigenous dissolved organic carbon in river-influenced ocean margins. Limnol. Oceanogr. 57, 1453-1466 (2012).

48. Helms, J. R. et al. Absorption spectral slopes and slope ratios as indicators of molecular weight, source, and photobleaching of chromophoric dissolved organic matter. Limnol. Oceanogr. 53, 955-969 (2008).

49. Stedmon, C. A., Markager, S. \& Kaas, H. Optical properties and signatures of chromophoric dissolved organic matter (CDOM) in Danish coastal waters. Estuar. Coast. Shelf Sci. 51, 267-278 (2000).

50. Murphy, J. \& Riley, J. P. A modified single solution method for the determination of phosphate in natural waters. Anal. Chim. Acta 27, 31-36 (1962).

51. Benner, R. \& Strom, M. A critical evaluation of the analytical blank associated with DOC measurements by high-temperature catalytic oxidation. Mar. Chem. 41, 153-160 (1993).

52. Jespersen, A. \& Christoffersen, K. Measurements of chlorophyll- $a$ from phytoplankton using ethanol as extraction solvent. Arch. Hydrobiol. 109, 445-454 (1987).
53. Smith, D. C. \& Azam, F. A simple, economical method for measuring bacterial protein synthesis rates in seawater using ${ }^{3} \mathrm{H}$-leucine. Mar. Microb. Food Webs 6, 107-114 (1992).

54. Gonzalez, P. R., Bouchet, S., Monperrus, M., Tessier, E. \& Amouroux, D. In situ experiments for element species-specific environmental reactivity of tin and mercury compounds using isotopic tracers and multiple linear regression. Environ. Sci. Pollut. Res. 20, 1269-1280 (2013).

\section{Acknowledgements}

We thank J Johansson and Claudia Bergin for assistance in the field and laboratory. Discussions with D Kothawala, S Sobek and B Obrador improved the manuscript. This research was funded by the Swedish Research Council (VR) grants to A.G.B. (project 2011-7192) and S.B. (grant 2012-3892 and 2013-6978), the Kempe Foundation (grants SMK-2745 to E.B. and SMK-2840 to Sy.B.) and the Swedish Research Council Formas (grant 2012-986 to S.B.). For J.T., the study has been conducted within a postdoctoral fellow financed by Umeå University and directed by Professor R Bindler and Professor J.-F. Boily.

\section{Author contributions}

A.G.B., Sy.B., E.B. and St.B. conceived the study. A.G.B. conducted the two sampling campaigns with assistance from Sy.B. and A.M.R. A.G.B. and Sy.B. performed the GC-ICP-MS analyses of $\mathrm{Hg}$ with guidance from E.B. J.T. conducted Py-GCMS analyses and data treatment for the molecular characterization of OM. A.G.B. and J.T. conducted all statistical analyses and built the figures with comments and suggestions from Sy.B., St.B., E.B. and A.M.R. Finally, A.G.B, Sy.B. and J.T. wrote the manuscript with significant assistance and comments from E.B., St.B. and A.M.R.

\section{Additional information}

Supplementary Information accompanies this paper at http://www.nature.com/ naturecommunications

Competing financial interests: The authors declare no competing financial interests.

Reprints and permission information is available online at http://npg.nature.com/ reprintsandpermissions/

How to cite this article: Bravo, A. G. et al. Molecular composition of organic matter controls methylmercury formation in boreal lakes. Nat. Commun. 8, 14255 doi: $10.1038 /$ ncomms14255 (2017).

Publisher's note: Springer Nature remains neutral with regard to jurisdictional claims in published maps and institutional affiliations.

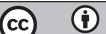

This work is licensed under a Creative Commons Attribution 4.0 International License. The images or other third party material in this article are included in the article's Creative Commons license, unless indicated otherwise in the credit line; if the material is not included under the Creative Commons license, users will need to obtain permission from the license holder to reproduce the material. To view a copy of this license, visit http://creativecommons.org/licenses/by/4.0/

(C) The Author(s) 2017 